\title{
The first study on seroprevalence and risk factors of Neospora caninum infection in pregnant local cows from Northeast Algeria
}

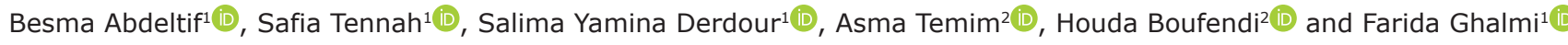 \\ 1. Research Laboratory Management of Local Animal Resources, Higher National Veterinary School, El Alia, Oued Smar, \\ 1615, Algiers, Algeria; 2. National Center for Biotechnology Research, Ali Mendjli New Town, Constantine, Algeria. \\ Corresponding author: Besma Abdeltif, e-mail: b.abdeltif@etud.ensv.dz \\ Co-authors: ST: s.tennah@ensv.dz, SYD: sy.derdour@ensv.dz, AT: a.temim@crbt.dz, HB: h.boufendi@crbt.dz, \\ FG: f.ghalmi@ensv.dz
}

Received: 22-09-2021, Accepted: 19-01-2022, Published online: 25-02-2022

doi: www.doi.org/10.14202/vetworld.2022.442-448 How to cite this article: Abdeltif B, Tennah S, Derdour SY, Temim A, Boufendi $\mathrm{H}$, Ghalmi F (2022) The first study on seroprevalence and risk factors of Neospora caninum infection in pregnant local cows from Northeast Algeria, Veterinary World, 15(2): 442-448.

\begin{abstract}
Background and Aim: Neospora caninum is one of the most common infectious organisms worldwide that causes abortion in cattle. To the best of our knowledge, no previous studies have focused on $N$. caninum infection in the local Atlas brown cattle from Northeast Algeria. This study aimed to assess the importance of bovine neosporosis for causing abortion in Atlas brown cattle and to identify selected risk factors.

Materials and Methods: A case-control study was performed on 60 control farms and 30 case farms. We collected 650 blood samples from 650 pregnant cows from 90 farms in five Algerian provinces; Jijel, Skikda, Annaba, El-Tarf, and SoukAhras. Sera samples were analyzed for the presence of antibodies against $N$. caninum using enzyme-linked immunosorbent assays.

Results: The seroprevalence of $N$. caninum infection in the cows was 36.2\% (95\% confidence interval [CI]: 32.7-39.8) and in the farms was $81.1 \%(95 \% \mathrm{CI}: 73.0-89.2)$. Risk factors found by multivariable logistic regression included: Presence of dogs (odds ratio [OR] 4.7, 95 CI 2.9-7.3); age $\geq 84$ months (OR 4.9, 95 CI 2.8-8.3); Jijel region (OR 2.2, 95 CI 1.1-4.5); white (OR 2.5, 95 CI 1.4-4.4) and gray (OR 2.5, 95 CI 1.4-4.5) coat; moderate (OR 2.30, 95 CI 1.4-3.8) and bad (OR 3.1, 95 CI 1.8-5.3) hygiene; and second (OR 2.5, 95 CI 1.4-4.4); and last (OR 2.3, 95 CI 1.3-4.2) stage of pregnancy. Our case-control study showed no significant association between seropositivity of $N$. caninum and abortion at the farms level (OR 0.9, 95 CI 0.3-2.7). Similarly, there was no significant association between seropositivity of $N$. caninum and abortion at the individual level (OR 0.8, 95 CI 0.6-1.2).

Conclusion: This is the first study of $N$. caninum infection in pregnant local cows from Northeast Algeria. The prevalence rate of antibodies against $N$. caninum was high. Almost all risk factors studied for infection were significantly associated with seroprevalence. Our analysis showed no relation between $N$. caninum infection and abortion. Consequently, these local cows are resistant to abortion caused by $N$. caninum.
\end{abstract}

Keywords: Algeria, Neospora caninum, pregnant cattle, seroepidemiology.

\section{Introduction}

Atlas brown cattle are a local variety of cattle in Northeast Algeria near the Tunisian border [1]. They are characterized by their coat color, which is used to distinguish them. The main varieties include: Guelmoise (gray coat); Cheurfa (white coat); and Setifienne (black coat). Another local variety of cattle is the Chelfienne (red coat), which is located in Northwest Algeria. Algeria had a total of 1.8 million cattle in 2018 [2]. The total national cattle distribution of Atlas brown cattle in Algeria is as follows: About $59 \%$ in the northeast; $22 \%$ in the center; $14 \%$

Copyright: Abdeltif, et al. Open Access. This article is distributed under the terms of the Creative Commons Attribution 4.0 International License (http://creativecommons.org/licenses/ by/4.0/), which permits unrestricted use, distribution, and reproduction in any medium, provided you give appropriate credit to the original author(s) and the source, provide a link to the Creative Commons license, and indicate if changes were made. The Creative Commons Public Domain Dedication waiver (http:// creativecommons.org/publicdomain/zero/1.0/) applies to the data made available in this article, unless otherwise stated. in the northwest; and 5\% in the south [1]. These cattle are characterized by low productivity due to genetic, nutritional, climatic, and health constraints.

Abortion is an economic issue for farmers. Neospora caninum is an apicomplexan protozoon that has been identified as a major cause of abortion in cattle worldwide, including Algeria $[3,4]$. Abortion is the primary clinical symptom of bovine neosporosis, with fetus death due to direct fetal or placental tissue damage between 3 and 8 months of pregnancy [5]. $N$. caninum infections have been reported worldwide [6]. Algerian studies on N. caninum in cattle have indicated varying prevalence levels in certain regions. Seroprevalence was $19.6 \%$ (157/799 imported, improved, and local cattle) from three provinces of North-Central Algeria [7], 12.4\% (23/186 dairy cattle) from five provinces of CentralNorthern Algeria [8], and 16\% (23/145 cows of Prim - Holstein) from Constantine, a Northeast Algeria Province [9]. In Algiers, there was 15\% (54/306 
cows) seropositivity in a case-control study [4]. The seroprevalence of $N$. caninum was $2 \%$ in Turkey [10], $8.5 \%$ in Morocco [11], $11 \%$ in Italy [12], $18.9 \%$ in Egypt [13], and 21.5\% in Tanzania [14]. To date, there have been no studies on the presence or absence of $N$. caninum in Atlas brown cattle in Northeast Algeria. This study aims to test the prevalence of antibodies to $N$. caninum and indicate risk factors associated with $N$. caninum seroprevalence in this region. A case-control study was carried out to determine the role of $N$. caninum in local cattle abortion. The aim of the casecontrol study is to assess the importance of $N$. caninum abortion in Algerian local cattle.

\section{Materials and Methods}

\section{Ethical approval and Informed consents}

No ethical approval was necessary for this study; however we obtained verbal informed consent from all farm owners involved in the study and we maintained the confidentiality of data obtained.

\section{Study period and areas}

The study was carried out from January 2017 to September 2019. The study was conducted in five provinces: Jijel, Skikda, Annaba, El-Tarf, and SoukAhras. These Provinces are located in North-East of Algeria. (Latitude: $36^{\circ} 53^{\prime} \mathrm{N}-36^{\circ} 16^{\prime} \mathrm{N}$, longitude: $\left.5^{\circ} 46^{\prime} \mathrm{E}-9^{\circ} 19^{\prime} \mathrm{E}\right)$. The geographical location of all districts selected in this study is indicated in Figure-1. The province's climate is typically the Mediterranean. Summer is hot and dry and winter is mild and humid. This study was performed in this region because it contains more than half of the local breed cattle livestock. It is concentrated in difficult areas, particularly mountains and forests. It is living in extensive system. This system is an integral part of family farming and the national economy [15].

\section{Animals and sera collection}

The selection criteria was pregnant Atlas brown cows. The sample size was calculated using the following formula.

$$
\mathrm{N}=1.96^{2} \mathrm{P}(1-\mathrm{P}) / \mathrm{D}^{2} \text {. }
$$

Where $\mathrm{N}$ was the sample size, 1.96 was the $\mathrm{Z}$ value for the selected confidence level (95\%), $\mathrm{P}$ was the individual disease prevalence, and $\mathrm{D}$ was the desired absolute precision. A minimum sample size of 600 animals was obtained using 50\% expected individual prevalence (since there was no previous study in this area), an absolute precision of $4 \%$, and a confidence level of $95 \%$. However, a total of 650 animals were included in this study to increase the precision. In total, 650 pregnant Atlas brown cows were selected from 90 farms in Northeast Algeria. Five milliliters of blood were taken from the jugular vein using dry vacutainer tubes (Becton-Dickinson, USA). The sera were separated with a centrifuge and then transferred to $2 \mathrm{~mL}$ micro-tubes and frozen at $-20^{\circ} \mathrm{C}$ until laboratory analysis. During farm visits, we conducted interviews with the farmers to collect data on the cattle (presence of dogs, abortion history, parity, age, coat color, and stage of pregnancy) and the farm (general hygiene, seasons, and region). Table-1 provides data collected during these visits.

\section{Case-control study}

The target population was pregnant local Atlas brown cows from Northeast Algeria. The research was carried out on each farm. A farm was considered a control if no abortion had occurred in the past 5 years. A case farm was any farm with at least one abortion in the past 5 years. In this area, two control farms of comparable size, husbandry, and management were chosen for each case farm. Data were collected from case and control farms. We used a structured face-toface interview with farm owners to collect this data. Ninety farms were selected in this study. Thirty of them were case farms, while the other sixty were controls. In total, 650 cows were examined, including 75 cows (case cows) with recent abortion events.

\section{Serological analysis}

Sera were tested for the presence of immunoglobulin $\mathrm{G}$ antibodies against $N$. caninum using an indirect multi-species enzyme-linked immunosorbent

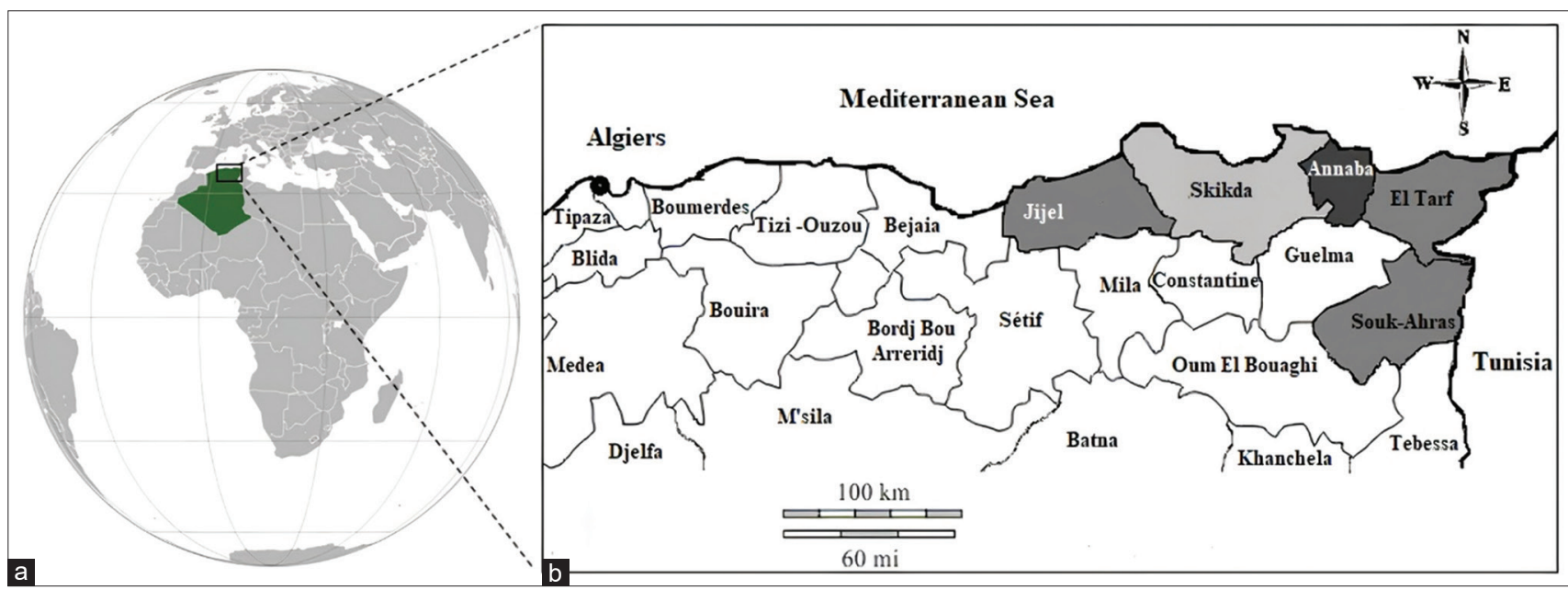

Figure-1: Map of the regions studied. (a) In Africa, Algeria. (b) Map of North-East Algeria; Sampled farms are indicated with gray areas [Source: modified from d-maps.com (https://dmaps.com/carte.php?num_car=4428\&lang=fr)]. 


\begin{tabular}{|c|c|c|c|c|c|c|}
\hline $\begin{array}{l}\text { Independent } \\
\text { variables }\end{array}$ & Categories & $\begin{array}{c}\text { No. of } \\
\text { examined cow }\end{array}$ & $\begin{array}{c}\text { No. of } \\
\text { positive cows }\end{array}$ & $\begin{array}{c}\text { Seroprevalence } \\
\%(95 \% \mathrm{CI})\end{array}$ & $\begin{array}{c}\text { Crude odds } \\
\text { ratio (95\% CI) }\end{array}$ & p-value \\
\hline \multirow{2}{*}{$\begin{array}{l}\text { Presence of } \\
\text { dogs }\end{array}$} & No & 271 & 55 & $20.3(15.5-28.1)$ & Ref. & \multirow[t]{2}{*}{$<0.001^{*}$} \\
\hline & Yes & 379 & 180 & $47.5(42.5-52.5)$ & $3.5(2.5-5.1)$ & \\
\hline \multirow[t]{2}{*}{ Abortion } & Yes & 75 & 28 & $37.3(26.4-48.3)$ & Ref. & \multirow[t]{2}{*}{0.82} \\
\hline & No & 575 & 207 & $36.0(32.8-39.9)$ & $1.0(0.6-1.7)$ & \\
\hline \multirow{3}{*}{$\begin{array}{l}\text { Age classes } \\
\text { (months) }\end{array}$} & $<36$ & 183 & 45 & $24.6(18.3-30.8)$ & Ref. & \multirow[t]{3}{*}{$<0.001^{*}$} \\
\hline & $36-84$ & 246 & 68 & $27.6(22.0-33.2)$ & $1.2(0.8-1.8)$ & \\
\hline & $\geq 84$ & 221 & 122 & $55.2(48.6-61.8)$ & $3.8(2.7-5.8)$ & \\
\hline \multirow[t]{3}{*}{ Parity } & Nulliparous & 190 & 50 & $26.3(20.0-32.6)$ & Ref. & \multirow[t]{3}{*}{$<0.001 *$} \\
\hline & Primiparous & 225 & 65 & $28.9(23.0-34.8)$ & $1.1(0.7-1.7)$ & \\
\hline & Multiparous & 235 & 120 & $51.1(44.7-57.5)$ & $2.9(1.9-4.4)$ & \\
\hline \multirow[t]{4}{*}{ Coat colors } & Black & 130 & 36 & $27.7(20.0-35.4)$ & Ref & \multirow[t]{4}{*}{$<0.001^{*}$} \\
\hline & Red & 124 & 16 & $12.9(07.0-18.8)$ & $0.4(0.2-0.7)$ & \\
\hline & White & 217 & 98 & $45.2(38.5-51.8)$ & $2.1(1.3-3.4)$ & \\
\hline & Gray & 179 & 85 & $47.5(40.2-54.8)$ & $2.4(1.4-3.8)$ & \\
\hline \multirow{3}{*}{$\begin{array}{l}\text { Stage of } \\
\text { pregnancy } \\
\text { (months) }\end{array}$} & $1-3$ & 133 & 30 & $22.6(15.4-29.7)$ & Ref. & \multirow[t]{3}{*}{$<0.001 *$} \\
\hline & $4-6$ & 275 & 118 & $42.9(37.1-48.8)$ & $2.6(1.6-4.1)$ & \\
\hline & $7-9$ & 242 & 87 & $36.0(29.9-42.0)$ & $1.9(1.2-3.1)$ & \\
\hline \multirow[t]{3}{*}{ Hygiene } & Good & 251 & 55 & $21.9(16.8-27.0)$ & Ref. & \multirow[t]{3}{*}{$<0.001^{*}$} \\
\hline & Moderate & 215 & 80 & $37.2(30.7-43.7)$ & $2.1(1.4-3.2)$ & \\
\hline & bad & 184 & 100 & $54.3(47.1-61.5)$ & $4.2(2.8-6.4)$ & \\
\hline \multirow[t]{4}{*}{ Seasons } & Autumn & 140 & 44 & $31.4(23.7-39.1)$ & Ref. & \multirow[t]{4}{*}{$<0.001 *$} \\
\hline & Winter & 157 & 49 & $31.2(24.0-38.5)$ & $1.0(0.6-1.6)$ & \\
\hline & Spring & 200 & 104 & $52.0(45.1-58.9)$ & $2.4(1.5-3.7)$ & \\
\hline & Summer & 153 & 38 & $24.8(18.0-31.7)$ & $0.7(0.4-1.2)$ & \\
\hline \multirow[t]{5}{*}{ area } & El-Tarf & 61 & 15 & $24.6(13.8-35.4)$ & Ref. & \multirow[t]{5}{*}{$<0.001 *$} \\
\hline & Annaba & 105 & 24 & $22.9(14.9-30.9)$ & $0.9(0.4-1.9)$ & \\
\hline & Skikda & 90 & 19 & $21.1(12.7-29.5)$ & $0.8(0.4-1.8)$ & \\
\hline & Souk-Ahras & 91 & 10 & $11.0(4.6-17.4)$ & $0.4(0.1-0.9)$ & \\
\hline & Jijel & 303 & 167 & $55.1(49.5-60.7)$ & $3.8(2.0-7.0)$ & \\
\hline
\end{tabular}

*Variables selected and used in the multivariable logistic regression model analysis $(p \leq 0.25)$. Ref.=Reference, $\mathrm{CI}=$ Confidence interval

assay (ELISA) commercial test (ID Screen ${ }^{\circledR} N$. caninum Indirect Mutlti-species; ID. vet, Innovative Diagnostics, Grabels, France) at the National Center for Biotechnology Research of Constantine, Algeria. This test has a sensitivity of $99.6 \%$ and a specificity of $97.3 \%$ for the serological diagnosis of bovine neosporosis [16]. The optical density of the ELISA microplates was estimated by an automatic plate reader (PerkinElmer, Waltham, USA) at $450 \mathrm{~nm}$. Seropositive animals were calculated using $\mathrm{S} / \mathrm{P} \%$ according to the manufacturer's instructions. Serum with $\mathrm{S} / \mathrm{P} \% \geq 50$ was considered positive, and the farm was considered positive when at least one farm serum sample responded positively.

\section{Statistical analysis}

All data were analyzed using Microsoft Office Excel 2016 and Statistical Package for the Social Sciences (SPSS) (SPSS. v.20, Chicago, IL, USA). Farm seroprevalence was determined by the ratio of positive farms to the total number of farms visited. A positive farm contained at least one seropositive cow. Cow seroprevalence was measured by the number of seropositive cows to the total number of cows examined. Confidence interval (CI) was constructed at the $95 \%$ level of confidence.

$\mathrm{CI}$ was calculated using the following formula: $\mathrm{CI}=\mathrm{P} \pm \mathrm{Pa}$.

$\mathrm{P}$ is seroprevalence obtained. $\mathrm{Pa}$ is absolute precision. Pa has been calculated using the following formula:

$$
\mathrm{Pa}=1.96 * \sqrt{\mathrm{P}(1-\mathrm{P}) / \mathrm{n}}
$$

The relationship between seroprevalence and neosporosis risk factors was determined using univariable and multivariable logistic regression models [17]. The first phase was a univariable analysis of variables by a Chi-square test and crude odds ratios (OR). In the multivariable analysis, significant variables at $\mathrm{p} \leq 0.2$ were chosen. The overall fit of the logistic regression models was tested with the Hosmer-Lemeshow test. When the OR was greater than 1 and $\mathrm{p} \leq 0.05$, variables were considered risk factors. Multifactorial correspondence analysis (MCA) was also performed and is a graphical presentation applicable to categorical data tables in addition to logistic regression [18].

\section{Results}

\section{Seroprevalence}

A total of 90 farms were visited, with samples obtained from 650 pregnant local cows. Farm seroprevalence was estimated at $81.1 \% \quad(95 \%$ CI: $73.0-89.2 \%$ ). Cow seroprevalence was $36.2 \%$ (95\% CI: 32.7-39.8\%).

\section{Risk factors analysis}

As shown in Table-1, there were 11 risk factors considered significant for the risk of $N$. caninum after the univariable analysis $(\mathrm{p}<0.2)$ : Presence 
of dogs; age $\geq 84$ months; spring season; multiparous cattle; Jijel region; white and gray coat; moderate and bad hygiene; and second and last stage of pregnancy. These factors were thus selected for multivariable logistic regression analysis. The results of this analysis were: Presence of dogs (OR 4.7, 95 CI 2.9-7.3); age $\geq 84$ months (OR 4.9, 95 CI 2.8-8.3); Jijel region (OR 2.2, 95 CI 1.1-4.5); white color (OR 2.5, 95 CI 1.4-4.4); gray color (OR 2.5, 95 CI 1.44.5); moderate hygiene (OR 2.30, 95 CI 1.4-3.8); bad hygiene (OR 3.1, 95 CI 1.8-5.3); second stage of pregnancy (OR 2.5, 95 CI 1.4-4.4); and last stage of pregnancy (OR 2.3, 95CI 1.3-4.2; Table-2). The model was a good fit for data (Hosmer and Lemeshow test with Chi-square $=8.9 ; \mathrm{df}=8 ; \mathrm{p}=0.3$ ). MCA was performed as a scatter plot to illustrate the variable groupings visually as they link to seropositivity or seronegativity (Figure-2). MCA showed that the presence of dogs (yes), white and gray coat color, second, and last trimesters of pregnancy (Stages 2 and 3), Jijel region, bad hygiene, spring season, age $\geq 84$ months, and multiparous cattle were grouped with seropositivity. In contrast, the absence of dogs (no), autumn, winter, and summer seasons, Annaba and Skikda region, first trimester of pregnancy (Stage 1), and good and moderate hygiene were grouped with seronegativity. Other factors were not associated with the serological results: Red coat, black coat, Souk-Ahras region, El-Tarf region, age $<36$ months $(<36)$, age between 36 and 84 months, primiparous cattle, and nulliparous cattle.

\section{Case-control study}

Forty-nine farms $(81.67 \%)$ out of 60 control farms were seropositive to $N$. caninum, and 11 farms $(18.3 \%)$ were seronegative. Twenty-four farms (80\%) out of 30 case farms were seropositive, and six farms $(20 \%)$ were seronegative. In the case and control farms, seroprevalence varied between $0 \%$ and $100 \%$. As shown in Table-3, the link between seroprevalence and abortion was calculated by an ORs. The OR (0.9, 95\% CI: 0.3-2.7) did not differ from one, indicating that there was no association of seroprevalence to $N$. caninum and the presence of abortion events on farms. Seroprevalence to N. caninum was the same in the control farms and case farms.
Of the 650 cows examined, 575 cows had not aborted (control cows) and 75 cows had recently aborted (case cows). Two hundred and sixty-one cows $(40.1 \%)$ were from case farms, and 389 (59.9\%) were from control farms. As shown in Table-4, the OR (0.8, 95 CI 0.6-1.2) did not differ from one in the case-control study at the individual level. The seroprevalence to $N$. caninum was the same in the control and case cows. Thus, seropositivity to $N$. caninum was not associated with cases of abortion in cattle; therefore, exposure to $N$. caninum is not synonymous with abortion.

\section{Discussion}

Our research identified the existence of $N$. caninum for the $1^{\text {st }}$ time in pregnant local cows in Algeria. This research was performed using an appropriate sample (650 cows) to determine cattle and farm seroprevalence and risk factors of $N$. caninum infection in Northeast Algeria. Furthermore, a case-control study was conducted to determine the association between contact with $N$. caninum and abortion. Individual seroprevalence was $36.2 \%$ $(235 / 650)$. This high seroprevalence is due to persistent contact between local cows and the parasite. This rate is higher than the seroprevalence rate previously reported in Algeria [4,7-9]. The seroprevalence in this study was higher than all seroprevalences reported in other Mediterranean and African countries: $2 \%$ in Turkey [10]; $3.4 \%$ in Nigeria [19]; $8.5 \%$ in Morocco [11]; $8.8 \%$ in Sudan [20]; $8.9 \%$ in South Africa [21]; $11 \%$ in Italy [12]; $17.9 \%$ in Senegal [22]; $18.9 \%$ in Egypt [13]; $21.5 \%$ in Tanzania [14]; $23.7 \%$ in Spain [23]; and $24.8 \%$ in pregnant cattle in Iran [24]. This variation registered might be due to the type of serological test used, the cutoff value used, region, sample size, sampling frame, farm management, contact with carnivores, breed, and climate effects, which are all known to affect results differently $[25,26]$. Farm seroprevalence was estimated at $81.1 \%(73 / 90)$, suggesting that the parasite is distributed in more than three-quarters of the studied herds. This result is higher than the $52.9 \%$ previously reported in three provinces in Northeast and Central Algeria [7]. Various studies have demonstrated substantial variance in the seroprevalence of $N$. caninum in herd

Table-2: Risk factors (logistic regression final model) associated with Neospora caninum seropositivity in pregnant local cows from North-Eastern Algeria.

\begin{tabular}{lccccc}
\hline Risk factor & B & SE & Odds ratio & Confidence interval 95\% & p-value \\
\hline Presence of dogs & 1.5 & 0.2 & 4.7 & $3.0-7.3$ & $<0.001$ \\
Age $\geq 84$ months & 1.6 & 0.3 & 4.9 & $2.8-8.3$ & $<0.001$ \\
Jijel area & 0.8 & 0.4 & 2.2 & $1.1-4.5$ & $<0.001$ \\
White color & 0.9 & 0.3 & 2.5 & $1.4-4.4$ & $<0.001$ \\
Grey color & 0.9 & 0.3 & 2.5 & $1.4-4.5$ & $<0.001$ \\
Moderate hygiene & 0.8 & 0.2 & 2.3 & $1.4-3.8$ & $<0.001$ \\
Bad hygiene & 1.1 & 0.3 & 3.0 & $1.8-5.3$ & $<0.001$ \\
Second stage of pregnancy & 0.9 & 0.3 & 2.5 & $1.4-4.4$ & $<0.001$ \\
Last stage of pregnancy & 0.8 & 0.3 & 2.3 & $1.3-4.2$ & $<0.001$ \\
\hline
\end{tabular}

$\mathrm{B}=$ Regression coefficient, $\mathrm{SE}=$ Standard error, Likelihood ratio 591.2, Chi-square goodness of fit test $=8.9 ; \mathrm{df}=8 ; \mathrm{P}=0.3$

Veterinary World, EISSN: 2231-0916 


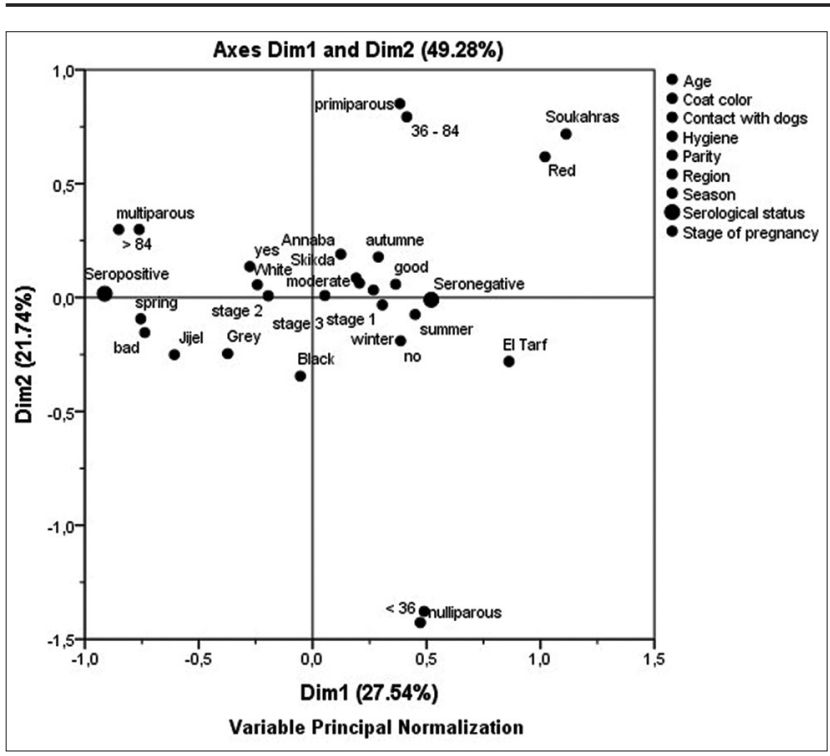

Figure-2: Plot of multiple correspondence analysis related to factors associated with seroprevalence of Neospora caninum.

Table-3: Association between seroprevalence and abortion at the farms level.

\begin{tabular}{lcc}
\hline Test & Case farm & Control farm \\
\hline Seropositive & 24 & 49 \\
Seronegative & 6 & 11 \\
Total & 30 & 60 \\
Seroprevalence & $80 \%$ & $81.7 \%$ \\
Odds ratio (confidence & \multicolumn{2}{c}{$0.9(0.3-2.7)$} \\
interval 95\%) & \multicolumn{2}{c}{} \\
\hline
\end{tabular}

Table-4: Association between seroprevalence and abortion at the individual level.

\begin{tabular}{lcc}
\hline Test & $\begin{array}{c}\text { Cows from } \\
\text { case farm }\end{array}$ & $\begin{array}{c}\text { Cows from } \\
\text { control farm }\end{array}$ \\
\hline Seropositive & 89 & 146 \\
Seronegative & 172 & 243 \\
Total & 261 & 389 \\
Seroprevalence & $34.1 \%$ & $37.5 \%$ \\
Odds ratio (confidence & \multicolumn{2}{c}{$0.8(0.6-1.2)$} \\
interval 95\%) & \multicolumn{2}{c}{} \\
\hline
\end{tabular}

cattle, including Italy $44.1 \%$ [27], Sudan 32.2\% [20], and Spain $80.6 \%$ [23].

Seropositivity risk factors in this study included: presence of dogs; aged $\geq 84$ months; originating in the region of Jijel; white color; gray color; average and poor hygiene; and the second and last stages of pregnancy. Seroprevalence increases when dogs are present; dogs are definitive hosts. N. caninum contaminates feeding areas of infected dogs with oocysts; thus, cattle are infected horizontally through ingestion of the infectious oocysts shed by dogs [28]. In our research, seroprevalence increased with age and was high in animals aged equal to or more than 84 months. This suggests that horizontal transmission in this population was more prevalent than vertical transmission. The previous literature has shown an association between age and seroprevalence in bovine neosporosis; nevertheless, this association is conflicting. Jensen et al. [29] suggested that age increases the risk of infection, but Sanderson et al. [30] reported that cows under 3 years old had antibody titers to $N$. caninum that were higher than cows over 6 years old.

For the $1^{\text {st }}$ time, the correlation between neosporosis infection and various cow colors was tested, with a significant difference between seropositivity and cow color. Gray and white-coated cows were more susceptible to infection, and the Jijel region cows are gray and white. In addition, the relationship between seropositivity and Jijel region was positive. This result needs to be interpreted carefully. Cows in the Jijel region live in an extensive system in mountains and forests, where various animals (dogs, wild canids, and cows) coexist, making horizontal transmission easier.

Hygiene also played a role, with the number of seropositive cows high on farms with poor hygienic conditions. A significant difference was found in farms with bad and moderate hygienic conditions than farms with good hygienic conditions. Improper cleaning increases feed and water contamination risk with N. caninum oocysts.

A significant difference in seroprevalence was also observed in gestational stage. Cows in the first trimester of pregnancy (1-3 months) had a low seroprevalence compared to cows in the second and last trimesters of pregnancy ( $\geq 4$ months). This indicates that the immune system of pregnant cows is more exposed to $N$. caninum during the middle and late stages of pregnancy than in the first stage. This exposure to $N$. caninum could be due to re-infection or reactivation of the encysted parasites in tissue after the initial infection. Globally, multiple studies have suggested that cows seropositive to $N$. caninum have a higher risk for abortion than seronegative cows, including Algeria [7,24,25,31,32]. The case-control studies performed to determine the relationship between $N$. caninum antibodies and abortion in animal farms previous case-control study results have shown a significant association between seropositivity and abortion at the farm level (OR 0.9, 95 CI 0.3-2.7) and the individual level (OR 0.8, 95 CI 0.6-1.2). However, the findings of this study do not support the previous research, as the OR values varied significantly from one. The OR varied from 2.2 [33], 2.56 [4], 3.36 [34], 8 [35], 12.0 [7] to 22.1 [27] in this research. Thus, abortion episode occurrence does not link to seropositive animal presence in Atlas brown cows of Northeast Algeria.

\section{Conclusion}

This is the first study of $N$. caninum infection in pregnant Atlas brown cows in Northeast Algeria. Seropositivity to $N$. caninum was high in these cows. Risk factors for the occurrence of antibodies to N. caninum included dog, age, location, color, and hygiene. Horizontal transmission of $N$. caninum is probably the most important mode of infection in this region. Our analysis showed no relation between $N$. caninum infection and abortion; thus, neosporosis 
should not be used as a differential diagnosis for abortion in these cattle. We recommend increasing the geographical area of study to confirm the conclusions obtained in this study. Research on the mechanism of resistance of Atlas brown cows to abortions will have to be done by genetic study. The future study should be based on identifying the gene(s) involved and the underlying mechanisms.

\section{Authors' Contributions}

FG, ST: Planned the study. BA: Collected samples, provided serological analyses, analyzed the data, and wrote the manuscript. SYD, AT, and HB contributed to serological analyses. FG: Supervised the study and revised the manuscript. All authors read and approved the final manuscript.

\section{Acknowledgments}

The authors are thankful to the Higher National Veterinary School and Research Laboratory Management of Local Animal Resources of Higher National Veterinary School Algiers, Algeria, for providing all the facilities to carry out the present study. We are thankful to Mr. Bernard China for his helpful advice in preparing the manuscript. We acknowledge the farmers for their willingness to participate and provide information about their farms and animals. The authors did not receive any funds for this study.

\section{Competing Interests} interests.

The authors declare that they have no competing

\section{Publisher's Note}

Veterinary World remains neutral with regard to jurisdictional claims in published map and institutional affiliation.

\section{References}

1. AnGR (Animal Genetic Resources). (2003) Rapport National sur les Ressources Génétique Animales, Ministère de l'Agriculture et du Développement Rural, Algérie [National Report on Animal Genetic Resources, Ministry of Agriculture and Rural Development, Algeria]. p46. Available from http://www.fao.org/3/a1250e/annexes/ CountryReports/Algeria.pdf. Retrieved on 17-08-2020.

2. FAOSTAT. (2020) Statistical Database 2018. Available from http://www.fao.org/faostat/fr/\#data/QA. Retrieved on 17-08-2020.

3. Cerqueira-Cézar, C.K., Alero-Bernal, R., Dubey, J.P. and Gennari, S.M. (2017) All about neosporosis in Brazil. Rev. Bras. Parasitol. Vet., 26(3): 253-279.

4. Derdour, S.Y., Hafsi, F., Azzag, N., Tennah, S., Laamari, A., China, B. and Ghalmi, F. (2017) Prevalence of the main infectious causes of abortion in dairy cattle in Algeria. $J$. Vet. Res., 61(3): 337-343.

5. Nicolino, R.R., de Oliveira, C.S.F., Lopes, L.B., Rodrigues, R.O. and Haddad, J.P.A. (2017) Prevalence and risk factors associated with anti-Neospora caninum antibodies in dairy herds in the central region of Minas Gerais State, Brazil. Vet. Parasitol., 10(1): 71-74.

6. Snak, A., Garcia, F.G., Lara, A.A., Pena, H.F.J. and Osaki, S.C. (2018) Neospora caninum in properties in the west region of Paraná, Brazil: Prevalence and risk factors.
Rev. Bras. Parasitol. Vet., 27(1): 52-60.

7. Ghalmi, F., China, B., Kaidi, R. and Losson, B. (2011) Neospora caninum is associated with abortion in Algerian cattle. J. Parasitol., 97(6): 1121-1124.

8. Achour, K., Ben Mahdi, M.H., Akkou, M. and Teniou, X.R. (2012) Séroprévalence de Neospora caninum dans les élevages bovins laitiers de la région centre nord de l'Algérie. Rev. Sci. Technol. Int. Epiz [Seroprevalence of Neospora caninum in dairy cattle farms in the central northern region of Algeria. Rev. Sci. Technol. Int. Epiz], 31(3): 953-958.

9. Bouaziz, O., Dib, A.L., Aimeur, R., Lakhdara, N., Bouaziz, A. and Brerhi, E. (2013) Seroprevalence of Neospora caninum in dairy cattle in Eastern Algeria. Ann. Biol. Res., 4(11): 76-77. Available from http://scholarsresearchlibrary.com/AB. Retrieved on 25-08-2020.

10. Gökpınar, S. (2021) Seroprevalence of Neospora caninum and Besnoitia besnoiti in Cattle in Oğuzlar region. Türk. Parazitol. Derg., 45(2): 108.

11. Lucchese, L., Benkirane, A., Hakimi, I. and Idrissi, A.E. (2016) Seroprevalence study of the main causes of abortion in dairy cattle in Morocco. Vet. Ital., 52(1): 13-19.

12. Otranto, D., Llazari, A., Testini, G., Traversa, D., Frangipane di Regalbono, A., Badan, M. and Capelli, G. (2003) Seroprevalence and associated risk factors of neosporosis in beef and dairy cattle in Italy. Vet. Parasitol., 118(1-2): 7-18.

13. Fereig, R.M., Abou Laila, M.R., Mohamed, S.G.A., Mahmoud, H.Y.A., Ali, A.O., Ali, A.F., Hilali, M., Zaid, A., Mohamed, A.E.A. and Nishikawa, Y. (2016) Serological detection and epidemiology of Neospora caninum and Cryptosporidium parvum antibodies in cattle in Southern Egypt. Acta Trop., 162(1): 206-211.

14. Semango, G., Hamilton, C.M., Kreppel, K., Katzer, F., Kibona, T., Lankester, F., Allan, K.J., Thomas, K.M., Claxton, J.R., Innes, E.A., Swai, E., Buza, J., Cleaveland, S. and De glanville, W.A. (2019) The seroepidemiology of Neospora caninum in cattle in Northern Tanzania. Front. Vet. Sci., 6(1): 327.

15. Yakhlef, H. (1989) La Production Extensive du Lait en Algérie. In: Tisserand J-L Le lait Dans la Région Méditerranéenne. CIHEAM, Options Méditerranéennes: Série A. Séminaires Méditerranéens, Paris [Extensive Milk Production in Algeria. In: Tisserand J-L Milk in the Mediterranean Region. CIHEAM, Mediterranean Options: Series A. Mediterranean Seminars, Paris]. p135-139.

16. Álvarez-García, G. García-Culebras, A., GutiérrezExpósito, D., Navarro-Lozano, V., Pastor-Fernández, I. and Ortega-Mora, L.M. (2013) Serological diagnosis of bovine neosporosis: A comparative study of commercially available ELISA tests. Vet. Parasitol., 198(1-2): 85-95.

17. Fagerland, M.W. and Hosmer, D.W. (2016) Tests for goodness of fit in ordinal logistic regression models. J. Stat. Comput. Simul., 86(17): 3398-3418.

18. Greenacre, M. (2016) Correspondence Analysis in Practice. $3^{\text {rd }}$ ed. Chapman and Hall/CRC, London, United Kingdom. p326.

19. Ayinmode, A., Akinseye, V., Schares, G. and Cadmus, S. (2017) Serological survey of toxoplasmosis, neosporosis and brucellosis among cattle herds in Oyo state, SouthWestern Nigeria. Afr. J. Infect. Dis., 11(2): 95-101.

20. Ibrahim, A.M., Ismail, A.A., Angara, T.E.E. and Osman, M.O. (2014) Seroprevalence of Neospora caninum in dairy cattle and the co-herded camels, sheep and goats in dairy farms in the Khartoum State, Sudan. J. Appl. Ind. Sci., 2(5): 206-212.

21. Njiro, S.M., Kidanemariam, A.G., Tsotetsi, A.M., Katsande, T.C., Mnisi, M., Lubisi, B.A., Potts, A.D., Baloyi, F., Moyo, G., Mpofu, J., Kalake, A. and Williams, R. (2011) A study of some infectious causes of reproductive disorders in cattle owned by resource-poor farmers in Gauteng Province, South Africa. J. S. Afr. Vet. Assoc., 82(4): 213-218.

22. Kamga-Waladjo, A.R., Gbati, O.B., Kone, P., Lapo, R.A., 
Chatagnon, G., Bakou, S.N., Pangui, L.J., Diop Pel, H., Akakpo, J.A. and Tainturier, D. (2010) Seroprevalence of Neospora caninum antibodies and its consequences for reproductive parameters in dairy cows from Dakar-Senegal, West Africa. Trop. Anim. Health Prod., 42(5): 953-959.

23. Eiras, C., Arnaiz, I., Alvarez-García, G., OrtegaMora, L.M., Sanjuánl, M.L., Yus, E. and Diéguez, F.J. (2011) Neospora caninum seroprevalence in dairy and beef cattle from the Northwest region of Spain, Galicia. Prev. Vet. Med., 98(2-3): 128-132.

24. Gharekhani, J. and Yakhchali, M. (2019) Neospora caninum infection in dairy farms with history of abortion in West of Iran. Vet. Anim. Sci., 8(1): 100071.

25. Dubey, J.P., Schares, G. and Ortega-Mora, L.M. (2007) Epidemiology and control of neosporosis and Neospora caninum. Clin. Microbiol. Rev., 20(2): 323-367.

26. Ghalmi, F., China, B. and Losson, B. (2007) Diagnostic et surveillance épidémiologique de Neospora caninum [Diagnosis and epidemiological surveillance of Neospora caninum] Ann. Méd. Vét., 151(3): 123-149.

27. Sager, H., Fischer, I., Furrer, K., Strasser, M., Waldvogel, A., Boerlin, P., Audigé L. and Gottstein B. (2001) A Swiss case-control study to assess Neospora caninum-associated bovine abortions by PCR, histopathology and serology. Vet. Parasitol., 102(1-2): 1-15.

28. Schares, G., Bärwald, A., Staubach, C., Ziller, M., Kloss, D., Wurm, R., Rauser, M., Labohm, R., Drager, K., Fasen, W., Hess, R.G. and Conraths, F.J. (2003) Regional distribution of bovine Neospora caninum infection in the German state of Rhineland-Palatinate modelled by Logistic regression.
Int. J. Parasitol., 33(14): 1631-1640.

29. Jensen, A.M., Björkman, C., Kjeldsen, A.M., Wedderkopp, A., Willadsen, C., Uggla, A. and Lind, P. (1999) Associations of Neospora caninum seropositivity with gestation number and pregnancy outcome in Danish dairy herds. Prev. Vet. Med., 40(3-4): 151-163.

30. Sanderson, M.W., Gay, J.M. and Baszler, T.V. (2000) Neospora caninum seroprevalence and associated risk factors in beef cattle in the Northwestern United States. Vet. Parasitol., 90(1-2): 15-24.

31. Simsek, S., Utuk, A.E., Koroglu, E., Dumanli, N. and Risvanli, A. (2008) Seroprevalence of Neospora caninum in repeat breeder dairy cows in Turkey. Arch. Fur. Tierzucht, 51(2): 143-148.

32. Moore, D.P., Pérez, A., Agliano, S., Brace, M., Cantón, G., Cano, D., Leunda, M.R., Odeón, A.C., Odriozola, E. and Campero, C.M. (2009) Risk factors associated with Neospora caninum infections in cattle in Argentina. Vet. Parasitol., 161(1-2): 122-125.

33. Asmare, K. (2014) Neospora caninum versus Brucella spp. Exposure among dairy cattle in Ethiopia: A case-control study. Trop. Anim. Health Prod., 46(6): 961-699.

34. Sanhueza, J.M., Heuer, C. and West, D. (2013) Contribution of Leptospira, Neospora caninum and bovine viral diarrhea virus to fetal loss of beef cattle in New Zealand. Prev. Vet. Med., 112(1-2): 90-98.

35. Václavek, P., Koudela, B., Modrý, D. and Sedlák, K. (2003) Seroprevalence of Neospora caninum in aborting dairy cattle in the Czech Republic. Vet. Parasitol., 115(3): 239-245. 